\section{Jefferson}

Thomas Jefferson University

HOME OF SIDNEY KIMMEL MEDICAL COLLEGE
Jefferson Currents: The Energy

Conservation Newsletter

Volume 6

Issue 1 Spring 2005

Article 1

2005

\title{
Jefferson Currents: Spring 2005
}

Follow this and additional works at: https://jdc.jefferson.edu/jeffersoncurrents

Part of the Natural Resources and Conservation Commons Let us know how access to this document benefits you

\section{Recommended Citation}

(2005) "Jefferson Currents: Spring 2005," Jefferson Currents: The Energy Conservation Newsletter. Vol. 6 : Iss. 1 , Article 1.

Available at: https://jdc.jefferson.edu/jeffersoncurrents/vol6/iss1/1

This Article is brought to you for free and open access by the Jefferson Digital Commons. The Jefferson Digital Commons is a service of Thomas Jefferson University's Center for Teaching and Learning (CTL). The Commons is a showcase for Jefferson books and journals, peer-reviewed scholarly publications, unique historical collections from the University archives, and teaching tools. The Jefferson Digital Commons allows researchers and interested readers anywhere in the world to learn about and keep up to date with Jefferson scholarship. This article has been accepted for inclusion in Jefferson Currents: The Energy Conservation Newsletter by an authorized administrator of the Jefferson Digital Commons. For more information, please contact: JeffersonDigitalCommons@jefferson.edu. 


\section{On the Home Front}

\section{Be Cool!}

The Alliance to Save Energy (ASE) and Procter \& Gamble are challenging each of us to switch to washing clothes in cold water to save both money and energy. In fact, switching to cold water for washing clothes can save each of us about $\$ 60$ to $\$ 90$ annually, depending on whether we use natural gas or electricity to heat our water.

ASE (and us!) urge you to accept the Challenge and save energy, money and the planet. Tide will even send you a free sample of Tide Coldwater to get you started. Tide Coldwater is also donating $\$ 100,000$ to the National Fuel Funds Network, a group that assists state and local groups helping low-income families pay their energy bills. Check out the Challenge at www.coldwaterchallenge.com.

\section{Keep Pluggin' Away!}

Please sit down. You may not be ready for this statistic, folks — there are five battery chargers for every man, woman and child in this country.

Together, these chargers total 1.5 billion power adapters that are plugged in daily for our cell phones, digital cameras, laptop computers and MP3 players. These battery chargers tend to be very inefficient. Their collective energy bill runs an astounding $\$ 17$ billion annually.

An adapter that has earned the Energy Star mark uses 35\% less energy than conventional models. In addition, they're frequently lighter and smaller in size, which makes it easier for consumers to transport products like laptop computers. Check out www.energystar.gov/index.cfm?c=prod_development.external_EPS_program for more details.

You could also use a solar-powered battery charger to fire up small electronic products, such as cell phones and iPods. Better Energy Systems makes a nifty charger called "Solio" that you expose to the sun's rays instead of plugging it into an outlet in order to charge that PDA, etc. (\$100 to $\$ 120 ;$ www.solio.com). Music, powered by the sun — a great idea!

\section{Bright Ideas}

And the Winner Is...

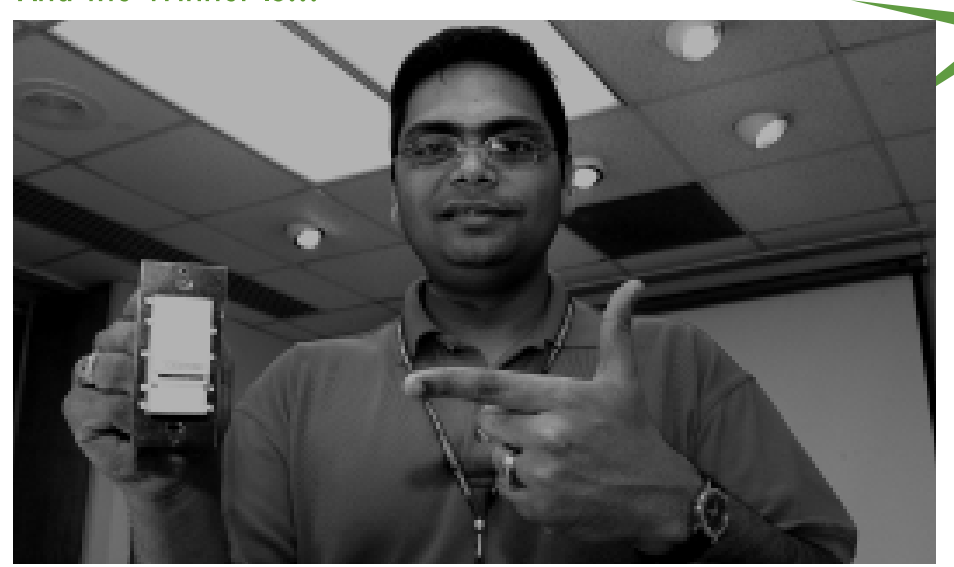

Lokesh Agrawal, Research Associate, Department of Pathology, the winner of the $\$ 100$ award for best suggestion is seen here holding a lighting control sensor for his suggestion to install automatic lighting control devices in common areas (conference rooms, bathrooms, etc.) to turn off lights when they are unoccupied. Congratulations Lokesh!

\begin{tabular}{|cccc|}
\hline \multicolumn{4}{c|}{ Savings at Work - Center City Campus } \\
Oct-Dec 2004 & Budget & Actual & Prior Year Actual \\
Electricity & $\$ 1,736,000$ & $\$ 1,657,938$ & $\$ 1,651,195$ \\
Steam & $1,502,000$ & $1,533,060$ & $1,408,601$ \\
Water & 283,000 & 195,614 & 163,326 \\
\hline
\end{tabular}

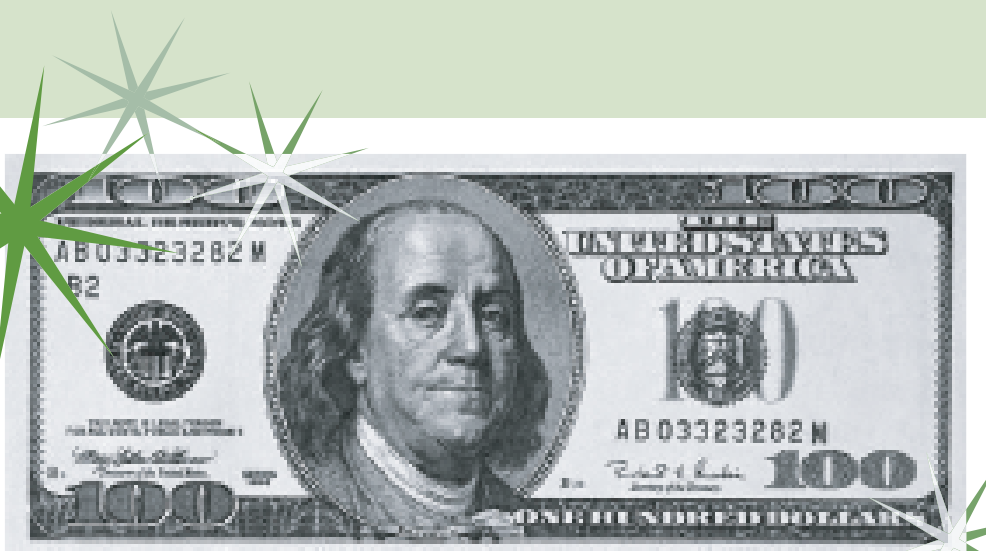

Don't stop looking for ways to cut energy use around here.We need your input and are counting on you. We're also counting out the bucks - don't forget, we'll be awarding a $\$ 100$ bill to that person who submits the best idea for cutting energy use on campus.

\section{The Future}

Did you know that Pennsylvania is the largest producer of wind powered electricity east of the Mississippi?

\section{Look around your area and observe operations, develop a good idea to lower energy use and then call me, Randy Haines at 503-6099 or email me at randolph.haines@jefferson.edu.}

